\title{
Is pedal melanoma among a Nigerian ethnic group preventable?
}

\author{
Abstract \\ The characteristic pigmentation of the melanoma lightened the problem of its diagnosis \\ from the 19th century. No wonder that museums illumined their stature in pathology. \\ Nowadays, epidemiological papers point to the selection of the foot as the premier site \\ of melanoma in the tropics. A preliminary paper by the author concerning the Igbo ethnic \\ group in South-Eastern Nigeria suggested the pedal origin of most melanomas. Therefore, \\ this paper aims to verify this presumption with a larger cohort. The highlights in 124 cases \\ were \\ a. Equal male/female ratio \\ b. 61-70 group preponderance \\ c. The sole as the most frequently attacked pedal site \\ d. Submission of specimens from 20 towns other than Enugu, the erstwhile Capital City \\ of the Regional Government.
}

Keywords: melanoma, age, sex, site, sole, towns, igbos, nigeria
Volume 8 Issue I - 2017 Wilson Onuigbo
Department of Pathology, Medical Foundation and Clinic,
Nigeria

Correspondence: Wilson Onuigbo, Department of Pathology, Medical Foundation and Clinic, 8 Nsukka Lane, Enugu 40000I, Nigeria, Tel 2.35E+12, Email wilson.onuigbo@gmail.com

Received: April 10, 2017 | Published: June 08, 2017

\section{Introduction}

During the $19^{\text {th }}$ century, the study of melanoma was relatively easy on account of its intrinsic melanin pigmentation. Remarkably, as I have documented, there was not much difficulty in respect of such primarily attacked organs as the breast, ${ }^{1}$ kidney, ${ }^{2}$ bone, ${ }^{3}$ adrenal glands, ${ }^{4}$ and liver. ${ }^{5}$ Indeed, museums illumined them. ${ }^{6}$ Nowadays, epidemiologic papers on the foot as the organ of site of origin are being promoted. ${ }^{7-11}$ Therefore, the present paper documents the findings from my Nigerian personal experience.

\section{Materials and methods}

Following the suggestion of a Birmingham (UK) group that the establishment of a histopathology data pool helps in epidemiological analysis, ${ }^{12}$ this paper is hinged on the findings obtained from 1970 onwards regarding the Igbo ethnic group ${ }^{13}$ with reference to the author's experience in a regional such data pool. To it, did several doctors submit biopsy specimens accompanied by clinical data on locally diagnosed melanomas? In particular, the author's personal findings on such materials are deemed worthy of documentation and publication.

\section{Results}

It is apparent that the male/female ratio of $64 / 60$ is almost equal. Moreover, the 61-70 age groups predominated in both sexes (Table 1). As to the sites of origin, the sole preponderated (Table 2). Incidentally, the 23 cases sent under "Foot" would have swelled the "Sole" cases if more care in site identification had been taken by the clinicians who had submitted them.

The melanoma scenery may be summed up, as did Houghton \& Viola, ${ }^{14}$ as follows: "melanoma in darker races tends to occur on the foot and mucous membranes:" However, as regards my above study among the Igbos, the mucous membranes are so scarce as to require future individual case reports, e.g., on anus, and vulva.
Table I Age-sex distribution pattern of patients

\begin{tabular}{llll}
\hline Age $(\mathbf{y r})$ & $\mathbf{M}$ & $\mathbf{F}$ & Total \\
\hline$<30$ & $\mathrm{I}$ & 2 & 3 \\
$3 I-40$ & 2 & 3 & 5 \\
$4 I-50$ & 8 & $\mid 4$ & 22 \\
$5 I-60$ & 20 & 15 & 35 \\
$6 I-70$ & 28 & 22 & 50 \\
$7 \mid+$ & 5 & 4 & 9 \\
Total & 64 & 60 & 124 \\
\hline
\end{tabular}

Table 2 Number in sites of observed origins

\begin{tabular}{ll}
\hline Site & No. \\
\hline Sole & 72 \\
Foot & 23 \\
Heel & 17 \\
Toe & 8 \\
Border & 4 \\
Total & 124 \\
\hline
\end{tabular}

\section{Conclusion}

In conclusion, it was surmised long ago that the role of the heat of the hot soils of Africa should be investigated with regard to the causation of pedal melanoma. ${ }^{15}$ My recent attempt at personal calculations with the local data did not confirm this hypothesis. ${ }^{16}$ Perhaps, the series is not yet long enough!

\section{Funding}

None.

\section{Acknowledgements}

None. 


\section{Conflicts of interests}

The authors declare that there is no conflict of interest.

\section{References}

1. Onuigbo WIB. The spread of melanoma to the breast: Historical notes. EC Cancer. 2016;2(2):100-101.

2. Onuigbo WIB. Metastasis of melanoma to the kidney: Historical notes. J Can Epi Treat. 2016;1(2):17-18.

3. Onuigbo WIB. The spread of melanoma to bone: Historical perspectives. Orthoped Ortho \& Rheum Open Access J. 2016; 2(1):01-02.

4. Onuigbo WIB. The spread of melanoma to the adrenal glands: Historical cases. Clin Med Rev Case Rep. 2016;3:105.

5. Onuigbo WIB. Anatomical mapping of the liver with melanoma metastases: Historical Method. Anat Physiol. 2016;6(2): 1000210.

6. Onuigbo WIB. Melanomas in museums: Historical highlights. Ann Carcinogen. 2016;1(1):1005.

7. Dwyer PK, Mackie RM, Watt DC, et al. Plantar malignant melanoma in a white Caucasian population. Br J Dermatol 1993;128(2):115-120.

8. Walsh SM, Fisher SG, Sage RA. Survival of patients with primary pedal melanoma. J Foot Ankle Surg. 2003;42(2):193-198.
9. Greenway HT, Twersky JM, Meads SB, et al. Melanoma of the foot and ankle: A case series of an underrecognized entity. Arch Dermatol. 2007;143(4):543-544.

10. Bristow IR, Bowling J. Dermoscopy as a technique for the early identification of foot melanoma. J Foot Ankle Res. 2009;2: 14.

11. Bristow IR, de Berker DAR, Acland KM, et al. Clinical guidelines for the recognition of melanoma of the foot and nail unit. $J$ Foot Ankle Res. 2010;3:25.

12. Macartney JC, Rollaston TP, Codling BW. Use of a histopathology data pool for epidemiological analysis. J Clin Pathol. 1980;33(4):351-355.

13. Basden G. Niger Ibos. Frank Cass, London. 1966.

14. Houghton AN, Viola MV. Solar radiation and malignant melanoma of the skin. J Am Acad Dermatol. 1981;5(4):477-483.

15. Davies JNP, Tank R, Meter R, et al. Cancer of the integumentary tissues in Uganda Africans: The basis for prevention. J Natl Cancer Inst. 1968;41(1):31-51.

16. Onuigbo WIB. The ratio of medullary breast carcinoma $(\mathrm{MBC})$ to invasive ductal carcinoma (IDC) is comparable in developed and underdeveloped countries. J Gynecol. 2017;2(S2): 000S2-007. 